Web Jurnal:

http://ejournal.kemenperin.go.id/jli

\title{
Penapisan, isolasi, dan karakterisasi mikroalga yang berpotensi sebagai sumber biodiesel dari perairan Danau Kerinci, Jambi
}

\section{Screening, isolation, and characterization of the potential microalgae as biodiesel source from Lake Kerinci, Jambi}

\author{
Riska Hernandi ${ }^{1}$, Abdi Dharma*2, A Armaini ${ }^{2}$ \\ 1 Program Pascasarjana Kimia, Universitas Andalas \\ Limau Manis, Pauh, Kota Padang, Sumatera Barat, Indonesia \\ 2 Laboratorium Biokimia, Universitas Andalas \\ Limau Manis, Pauh, Kota Padang, Sumatera Barat, Indonesia \\ * Corresponding author: \\ e-mail: abdipogil@gmail.com
}

\begin{tabular}{l}
\hline INFO ARTIKEL \\
\hline Sejarah artikel: \\
Diterima: \\
2 November 2018 \\
Direvisi: \\
21 April 2019 \\
Diterbitkan: \\
28 Juni 2019
\end{tabular}

\section{Kata kunci:}

isolasi;

mikroalga;

lipid;

asam lemak;

biodiesel

\begin{abstract}
ABSTRAK
Mikroalga menjadi sumber minyak nabati yang berpotensi sebagai bahan baku pembuatan biodiesel dengan kandungan lipid $30-70 \%$ dari berat biomassa kering dan komposisi asam lemak yang lengkap. Penelitian ini bertujuan untuk mempelajari keragaman spesies mikroalga dari perairan Danau Kerinci di Jambi, menganalisis kandungan lipid dan asam lemak isolat mikroalga. Mikroalga diisolasi dengan kombinasi teknik goresan, pengenceran berseri, dan mikropipet. Penentuan tingkat pertumbuhan dengan spektrofotometer UV-Vis. Penentuan berat biomassa kering secara gravimetri. Analisis kualitatif lipid dengan uji nile red menggunakan mikroskop flourescence. Analisis kuantitatif lipid dengan ekstraksi menggunakan n-heksana. Analisis kandungan asam lemak dengan alat GC-MS. Terdapat 19 spesies mikroalga yang diidentifikasi dan 2 spesies berhasil ditapis dengan stres salinitas, yaitu MA1 (Scenedesmus rubescens) dan MA2 (Galdieria sulphuraria). MAI dan MA2 memiliki kandungan lipid yang lebih tinggi pada pupuk Growmore dibandingkan pada medium Bold's Basal. MA1 memiliki kandungan lipid 31,95\% pada medium Bold's Basal dan 32,4\% pada pupuk Growmore. MA2 memiliki kandungan lipid 28,72\% pada medium Bold's Basal dan 28,93\% pada pupuk Growmore. Mikroalga MA1 dan MA2 dapat dijadikan sumber biodiesel dengan kandungan lipid dan asam lemak jenuh (C16:0, C18:0) yang tinggi.
\end{abstract}

\section{Keywords:}

isolation;

microalgae;

lipid;

fatty acid;

biodiesel

\begin{abstract}
Microalgae has been considered recently as a promising biomass feedstock with great potential for biodiesel production with 30-70\% lipid content of the dry biomass weight and produces high fatty acid. This research investigated the diversity of microalgae species from waters of Lake Kerinci in Jambi and analysis of the lipid content and fatty acid of microalgae. The isolation was done by agar plate, serial dilution, and micropipette method. The growth rate of the isolated microalgae was determined by $U V$ Vis spectrophotometer. Dry biomass weight was determined gravimetrically. Nile red staining performed on the isolates to observe the potential of lipid content. Lipids were extracted using n-hexane. Fatty acid analysis by GC-MS. From the results of identification, there were 19 species of microalgae and 2 species were screened with salinity stress. Based on identification of the both isolates, it is known that MA1 isolate is Scenedesmus rubescens and MA2 is Galdieria sulphuraria. MAI and MA2 had higher lipid content in Growmore agrolyzer than Bold's Basal medium. MAl had lipid content $31.95 \%$ in Bold's Basal medium and $32.4 \%$ in Growmore agrolyzer, MA2 had lipid content $28.72 \%$ in Bold's Basal medium and $28.93 \%$ in Growmore agrolyzer. MA1 and MA2 was a potential as a biodiesel source with high lipid content and saturated fatty acids (C16:0, C18:0).
\end{abstract}




\section{Pendahuluan}

Pemenuhan kebetuhan energi saat ini masih didominasi bahan bakar fosil. Kebutuhan sumber energi tersebut setiap tahun semakin meningkat, sehingga peningkatan kebutuhan minyak di dunia mengakibatkan cadangan minyak dunia semakin menipis. Energi fosil merupakan energi yang terbatas dan kurang ramah lingkungan. Proses pembakarannya menghasilkan efek yang kurang baik bagi lingkungan dan kesehatan (Patil et al., 2008). Eksplorasi sumber energi alternatif non minyak bumi seperti energi surya, energi geotermal, energi angin dan biodiesel mulai digalakkan. Biodiesel termasuk salah satu bentuk pengembangan bioenergi yang merupakan bagian dari diversifikasi energi yang memanfaatkan bahan hayati sebagai sumber energi atau bahan bakar (Mata et al., 2010).

Biodiesel menjadi bahan bakar alternatif ramah lingkungan yang berpotensi menjadi solusi menurunkan kadar gas $\mathrm{CO}_{2}$ di udara yang saat ini sudah melebihi ambang batas (Bartley et al., 2013). Biodiesel dibuat melalui esterifikasi atau transesterifikasi minyak nabati dengan katalis asam atau basa sehingga menghasilkan metil ester (Mata et al., 2013). Upaya pengembangan biodiesel hingga saat ini masih mengalami berbagai kendala dan permasalahan, seperti sumber bahan baku yang relatif mahal dan adanya isu kompetisi terhadap kebutuhan bahan pangan karena pada saat yang bersamaan pangan dan energi membutuhkan bahan baku yang sama sehingga dapat menyebabkan terjadi krisis pangan (Chisti, 2007).

Mikroalga merupakan salah satu sumber minyak nabati yang berpotensi sebagai bahan baku biodiesel. Mikroalga mengandung 30-70 \% minyak dari berat biomassa kering, sehingga dapat menghasilkan biodiesel sebanyak 58.700-136.900 L/ha dalam setahun, yang mana lebih besar dibandingkan produktivitas bahan baku lain seperti jagung (172 L/ha), kedelai (446 L/ha), canola (1.190 L/ha), jarak (1.892 L/ha), kelapa (2.689 L/ha) dan kelapa sawit (5.950 L/ha) (Gui et al., 2008). Keunggulan mikroalga dari sumber biodiesel lain, yaitu memiliki efisiensi fotosintesis tinggi, tidak berkompetisi dengan kebutuhan pangan, produksi biomassa dan tingkat pertumbuhan yang cepat serta dapat tumbuh dalam lahan terbatas (Musharraf et al., 2012). Mikroalga merupakan organisme yang dapat tumbuh pada lingkungan air tawar, payau, maupun air laut dengan salinitas tinggi (Duong et al., 2012).

Produksi lipid dan asam lemak pada setiap spesies mikroalga tergantung pada beberapa kondisi kultivasi, seperti salinitas, intensitas cahaya, temperatur, $\mathrm{pH}$, dan nutrien. Ketersediaan unsur hara seperti nitrogen $(\mathrm{N})$, fosfor $(\mathrm{P})$, kalium $(\mathrm{K})$ dan unsur hara lainnya merupakan faktor yang dapat mempengaruhi pertumbuhan dan komposisi metabolit mikroalga (Lee et al., 2013). Kandungan nitrogen dan unsur hara lainnya terdapat pada medium kultivasi, di mana medium paling umum digunakan adalah Bold's Basal Medium (BBM). Penggunaan BBM sebagai medium pertumbuhan mikroalga secara umum telah terbukti pengaruhnya, namun kurang ekonomis dari segi pembiayaan dikarenakan masing-masing komponen cukup mahal, sehingga penggunaan pupuk pertanian (agrolyzer) seperti pupuk Growmore menjadi alternatif. Selain ketersediaan nutrien pada media kultur, salinitas juga merupakan faktor yang berpengaruh terhadap pertumbuhan dan metabolisme mikroalga, seperti pada spesies mikroalga Botryococcus braunii yang laju pertumbuhan dan kandungan lipid meningkat dengan peningkatan $\mathrm{NaCl}$ dari 0 sampai $85 \mathrm{mM}$ (Rao et al., 2007), sedangkan Phaeodactylum tricornutum menghasilkan lipid dengan kandungan asam lemak total yang lebih tinggi pada salinitas 28 ppt dibandingkan pada 15, 20, dan 35 ppt (Qiao et al., 2016). Berdasarkan hal tersebut diketahui bahwa setiap spesies mikroalga memiliki laju pertumbuhan, produksi lipid dan asam lemak yang optimal pada salinitas medium tertentu. Dengan demikian, variasi salinitas perlu dilakukan pada medium pertumbuhan untuk menapis (screening) mikroalga yang dapat tumbuh dan memproduksi lipid dengan tinggi.

Hasil penelitian ini diharapkan bermanfaat sebagai bahan acuan dan informasi penting dalam penelitian lanjutan tentang pemanfaatan mikroalga sebagai sumber biodiesel, dalam upaya untuk mencari sumber bahan bakar alternatif yang dapat menjadi solusi untuk mencukupi kebutuhan di bidang energi terbarukan.

\section{Metode}

Alat-alat yang digunakan, yaitu plankton net, spektrofotometer UV-Vis (Thermo Scientific Genesyis 20), instrumen GC-MS (QP2010 Ultra Shimadzu), mikroskop binokuler (Olympus BX40), mikroskop fluoresens trinokuler (Olympus BX51), autoklaf (EScientific), aerator (Amara), oven (Memmert), sentrifuge (Nesco 80-2), sonikator (GT Sonic 1200), mikropipet $(M R O)$, pipet tetes (Pudak), neraca analitik (Kern ABS 220-4), dan peralatan kaca (Pyrex).

Bahan yang digunakan terdiri dari mikroalga yang diisolasi dari perairan Danau Kerinci, medium Bold's Basal $\left(\mathrm{NaNO}_{3}, \mathrm{MgSO}_{4} .7 \mathrm{H}_{2} \mathrm{O}, \mathrm{NaCl}, \mathrm{K}_{2} \mathrm{HPO}_{4}, \mathrm{KH}_{2} \mathrm{PO}_{4}\right.$, $\mathrm{CaCl}_{2} .2 \mathrm{H}_{2} \mathrm{O}, \mathrm{ZnSO}_{4} .7 \mathrm{H}_{2} \mathrm{O}, \mathrm{MnCl}_{2} .4 \mathrm{H}_{2} \mathrm{O}, \mathrm{CuSO}_{4} .5 \mathrm{H}_{2} \mathrm{O}$, $\mathrm{Co}\left(\mathrm{NO}_{3}\right)_{2} .6 \mathrm{H}_{2} \mathrm{O}, \mathrm{KOH}, \mathrm{FeSO}_{4} .7 \mathrm{H}_{2} \mathrm{O}, \mathrm{H}_{2} \mathrm{SO}_{4}, \mathrm{H}_{3} \mathrm{BO}_{3}$, ETDA), pupuk growmore, metanol, n-heksana, $\mathrm{NaCl}$, $\mathrm{H}_{2} \mathrm{SO}_{4}$, internal standar asam nonadekanoat, aquadest, formalin, nile red, dan aseton.

\subsection{Pengambilan sampel mikroalga}

Lokasi pengambilan sampel mikroalga di perairan Danau Kerinci, kabupaten Kerinci, Jambi. Secara geografis danau ini berada antara $2^{\circ} 7^{\prime} 28^{\prime \prime}$ sampai $2^{\circ} 8^{\prime} 14^{\prime \prime}$ Lintang Selatan dan 101 $26^{\prime} 50^{\prime \prime}$ sampai 101'31'34" Bujur Timur.

Pengambilan sampel mikroalga menggunakan plankton net dengan teknik vertikal, yaitu dengan menarik plankton net yang telah ditenggelamkan pada kedalaman 1 meter dan didiamkan selama 5 menit. Sampel air yang telah disaring dimasukan ke dalam botol dan diberi label. Beberapa $\mathrm{mL}$ sampel disimpan dan diberi formalin $4 \%$ untuk identifikasi keragaman mikroalga (Chaidir et al., 2016). 


\subsection{Pembuatan medium pertumbuhan mikroalga}

Medium pertumbuhan untuk kultivasi mikroalga, yaitu Bold's Basal Medium dan pupuk Growmore (Growmore 6-30-30, Growmore 10-55-10, Growmore 20-20-20, dan Growmore 32-10-10). Pembuatan 1 L medium BBM dilakukan dengan melarutkan $10 \mathrm{~mL}$ makronutrien dan $1 \mathrm{~mL}$ mikronutrien ke dalam $1 \mathrm{~L}$ akuades pada labu ukur. Pembuatan $1 \mathrm{~L}$ medium pupuk Growmore dilakukan dengan melarutkan 0,6 g pupuk Growmore pada 1 L aquades. Larutan disterilisasi di dalam autoklaf dan didinginkan hingga suhu ruang sebelum digunakan.

\subsection{Skrining mikroalga}

Skrining dilakukan dengan stres salinitas, karena dapat mempengaruhi pertumbuhan dan kandungan lipid mikroalga (Minhas et al., 2016). Mikroalga dikultivasi selama 25 hari pada medium pertumbuhan dengan konsentrasi $\mathrm{NaCl}$ berbeda 1, 3, dan $5 \mathrm{~g} / \mathrm{L}$. Kultur diamati dengan mikroskop setiap dua hari untuk mengetahui spesies mikroalga yang bertahan hidup terhadap stres salinitas (Salama et al., 2013).

\subsection{Isolasi mikroalga}

Mikroalga diisolasi dengan tiga teknik, yaitu teknik pengenceran berseri, teknik goresan, dan teknik mikropipet (Musharraf et al., 2012).

\subsection{Identifikasi mikroalga berdasarkan morfologi}

Isolat mikroalga diamati menggunakan mikroskop optik binokuler dan kamera digital untuk identifikasi morfologi. Sampel mikroalga diamati pada perbesaran sampai 1000x. Spesies mikroalga diidentifikasi taksonominya dengan membandingkan data morfologi spesies mikroalga yang terdapat pada website Algae Resource Database (algaebase.org).

\subsection{Seleksi medium pertumbuhan mikroalga}

Medium Bold's Basal, Growmore 6-30-30, Growmore 10-55-10, Growmore 20-20-20, dan Growmore 32-10-10 diseleksi untuk didapatkan medium paling sesuai untuk pertumbuhan mikroalga. Medium dengan laju pertumbuhan mikroalga cepat dan produksi biomassa tinggi digunakan sebagai medium pertumbuhan mikroalga untuk analisis selanjutnya.

\subsection{Penentuan tingkat pertumbuhan dan pemanenan biomassa mikroalga}

Pertumbuhan mikroalga ditentukan dengan pengukuran densitas optik dari kultur isolat mikroalga menggunakan spektrofotometer UV-Vis setiap hari pada panjang gelombang 440 dan 450 nm. Kurva pertumbuhan mikroalga dibuat berdasarkan data densitas optik yang diukur setiap hari selama 25 hari.

Pemanenan mikroalga dilakukan pada saat fase eksponensial yang didasarkan pada kurva pertumbuhan yang dibuat. Kultur dipanen secara mekanik dengan sentrifuge pada kecepatan 4000 rpm selama 10 menit. Endapan yang terbentuk dikeringkan untuk memperoleh biomassa kering mikroalga (Christenson and Sims, 2011).

\subsection{Penentuan berat biomassa kering mikroalga}

Biomassa kering mikroalga ditentukan beratnya berdasarkan kurva kalibrasi standar yang menghubungkan absorban (optical density) dan berat kering. Kultur isolat mikroalga pada densitas optik tertinggi diisi ke dalam lima buah botol vial yang telah ditimbang terlebih dahulu dengan volume masingmasing 4, 8, 12, 16, dan $20 \mathrm{~mL}$. Volume semua kultur tersebut dicukupkan menjadi $20 \mathrm{ml}$ dengan penambahan aquades sehingga membentuk isolat dengan lima variasi konsentrasi dan diukur densitas optiknya. Kultur dikeringkan dan ditimbang sampai didapatkan berat konstan. Data biomassa yang didapat dikonversi ke dalam satuan g/L. Kurva standar dibentuk dan disubstitusikan nilai densitas optik pada pertumbuhan optimal ke dalam persamaan regresi yang didapat, sehingga berat biomassa kering setiap isolat dapat ditentukan (Lee et al., 2013).

\subsection{Penentuan kandungan pigmen}

Kandungan pigmen mikroalga ditentukan dengan spektrofotometer UV-Vis. Kultur mikroalga sebanyak 2 $\mathrm{mL}$ disentrifugasi pada $4000 \mathrm{rpm}$ selama 5 menit. Pelet diambil, disuspensikan dalam $2 \mathrm{ml}$ metanol $90 \%$, dan diinkubasi dalam waterbath selama 30 menit pada $60{ }^{\circ} \mathrm{C}$. Sampel didinginkan pada suhu ruang dan disentrifugasi pada $4000 \mathrm{rpm}$ selama 5 menit. Pigmen terlarut diukur absorbansinya dengan spektrofotometer UV-Vis pada panjang gelombang $470 \mathrm{~nm}, 652 \mathrm{~nm}$, dan $665 \mathrm{~nm}$ (Litchtenthaler and Buschmann, 2001). Kandungan pigmen dihitung sesuai persamaan (1), (2), dan (3).

$$
\begin{aligned}
\text { Klorofil } \mathrm{a}= & \left(16,72 \times \mathrm{A}_{665}\right)-\left(9,16 \times \mathrm{A}_{652}\right) \\
\text { Klorofil } \mathrm{b}= & \left(34,09 \times \mathrm{A}_{652}\right)-\left(15,2 \times \mathrm{A}_{665}\right) \\
& \left(1000 \times \mathrm{A}_{470}\right)-(1,63 \times \text { Chlo } \mathrm{a})-(104,96 \times \mathrm{Chlo} \mathrm{b})
\end{aligned}
$$

221

\subsection{Analisis kandungan lipid secara kualitatif}

Analisis kualitatif lipid pada mikroalga dilakukan dengan metode pewarnaan nile red (9-diethylamino-5-

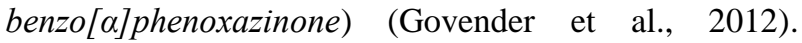
Larutan stok nile red disiapkan dengan dilarutkan $1 \mathrm{mg}$ nile red ke dalam $1 \mathrm{~mL}$ aseton. Sel mikroalga diwarnai dengan diteteskan $10 \mu \mathrm{L}$ larutan nile red ke dalam $1 \mathrm{~mL}$ kultur mikroalga. Proses pewarnaan berlangsung 20-30 menit. Sel mikroalga diamati dengan mikroskop flourescence dengan filter blue pada panjang gelombang 450-495 nm (Cooksey et al., 1987).

\subsection{Analisis kandungan lipid secara kuantitatif}

Mikroalga kering sebanyak $200 \mathrm{mg}$ diekstraksi dengan $20 \mathrm{~mL}$ n-heksana, disonikasi pada $35 \mathrm{~Hz}$ selama 
10 menit dan dimaserasi selama 12 jam. Sampel disentrifugasi pada $3500 \mathrm{rpm}$ selama 10 menit. Supernatan dipisahkan dan pelet diekstraksi kembali hingga lipid terekstrak semua dengan ditandai tidak adanya perubahan warna pada pelarut. Supernatan yang didapatkan diuapkan. Ekstrak lipid ditimbang hingga berat konstan (Raya et al., 2016). Perhitungan persentase dan produktivitas lipid mikroalga didasarkan pada persamaan (4) dan (5) (Dyer and Bligh, 1959).

$$
\% \text { Lipid }=\frac{\text { Berat Lipid Sampel }(\text { gram })}{\text { Berat Biomassa Sampel (gram) }} \times 100
$$

Produktivitas Lipid $(\mathrm{g} / \mathrm{L} /$ Hari $)=\frac{\text { Berat Lipid }(\text { gram }) / \text { Volume Kultur }(\mathrm{L})}{\text { Durasi Kultivasi }(\text { Hari })}(5)$

\subsection{Analisis kandungan asam lemak}

Ekstrak lipid diesterifikasi pada suhu $80{ }^{\circ} \mathrm{C}$ selama 1 jam dengan menggunakan metanol yang ditambahkan katalis $\mathrm{H}_{2} \mathrm{SO}_{4}$ dan internal standar. Hasil esterifikasi berupa metil ester asam lemak diekstraksi dengan n-heksana dan dianalisis menggunakan instrumen Gas Chromatograph-Mass Spectrometer (GC-MS) (Griffiths et al., 2010).

Metil ester sam lemak diinjeksikan sebanyak $1 \mu \mathrm{L}$ ke dalam kolom GC-MS dengan kondisi temperatur kolom dipertahankan pada suhu $70^{\circ} \mathrm{C}$ selama 1 menit kemudian ditingkatkan sampai $240^{\circ} \mathrm{C}$ pada kecepatan $3^{\circ} \mathrm{C} / \mathrm{min}$, dan temperatur injektor diatur pada $260^{\circ} \mathrm{C}$ (Praveenkumar et al., 2014).

\section{Hasil dan pembahasan \\ 3.1 Keragaman mikroalga}

Foto morfologi spesies mikroalga hasil identfikasi seperti pada Gambar 1.

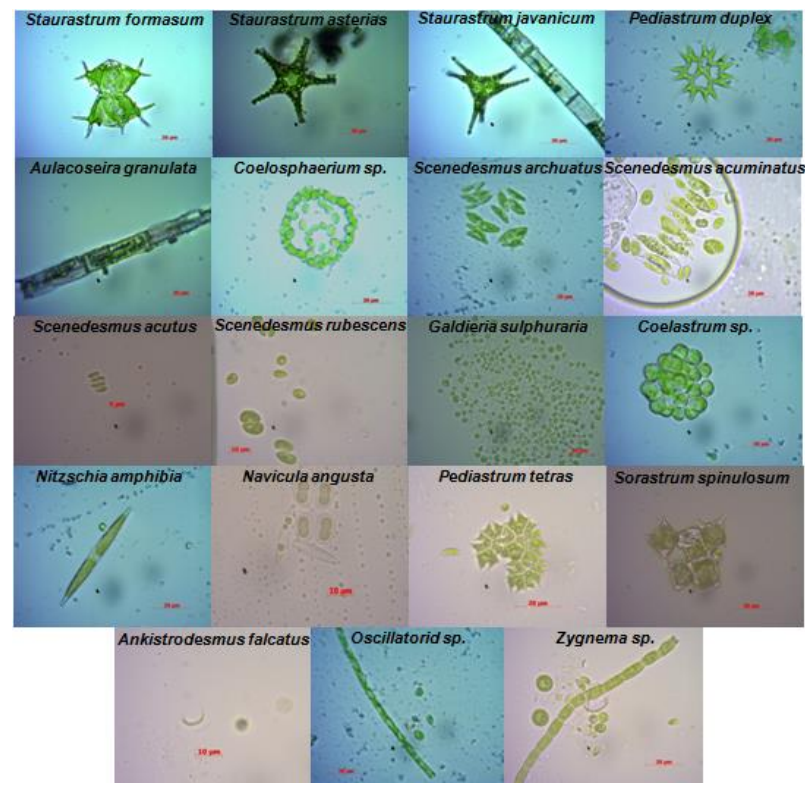

Gambar 1. Foto morfologi spesies mikroalga hasil identifikasi
Beberapa spesies mikroalga yang berhasil diidentifikasi termasuk dalam divisi Chlorophyta (alga hijau), Cyanophyta dan Bacillariophyta (Diatom). Mikroalga yang sering dijumpai pada perairan air tawar dengan penyebaran yang sangat luas pada umumnya adalah mikroalga dari divisi Chlorophyta, sedangkan pada perairan yang ekstrim banyak dijumpai mikroalga divisi Cyanophyta (Lee et al., 2013).

Spesies mikroalga yang berhasil diidentifikasi berdasarkan morfologi (Gambar 1), yaitu Staurastrum formasum, S. Asterias, S. javanicum, Pediastrum duplex, Aulacoseira granulata, Coelosphaerium sp., Scendesmus archuatus, S. acuminatus, S. acutus, S. rubescens, Galdieria sulphuraria, Coelastrum sp., Nitzschia amphibia, Navicula angusta, Pediastrum tetras, Sorastrum spinulosum, Ankistrodesmus falcatus, Oscillatorid sp., dan Zygnema sp.

\subsection{Mikroalga hasil skrining}

Skrining dilakukan untuk menseleksi mikroalga yang mempunyai kemampuan bertahan hidup pada kondisi stres salinitas. Hasil pengamatan dengan mikroskop terhadap mikroalga yang bertahan hidup pada kondisi stres $\mathrm{NaCl}$ terdapat pada Gambar 2.

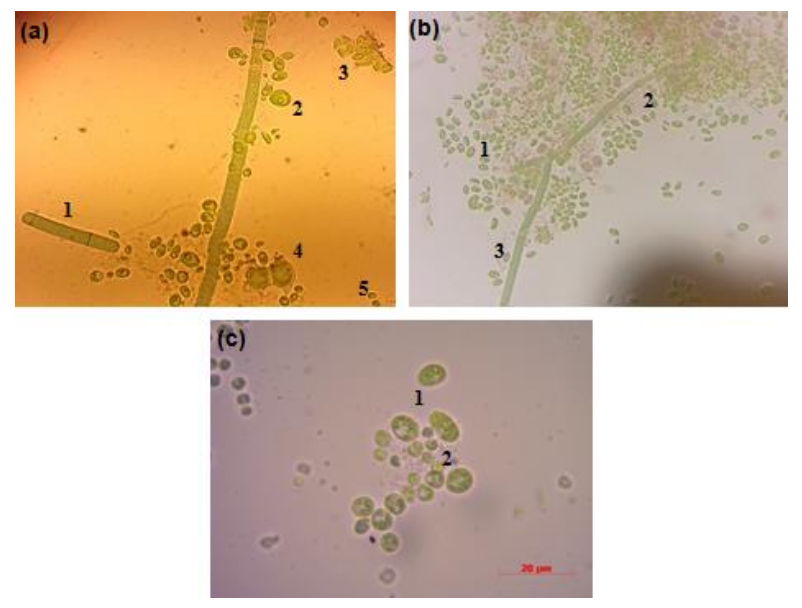

Gambar 2. Mikroalga hasil skrining (a) hari ke- 4, (b) hari ke- 6 , (c) hari ke-8

Berdasarkan hasil skrining, pada hari pertama sampai dengan hari ke- 3 masih terdapat 19 spesies mikroalga pada ketiga variasi konsentrasi $\mathrm{NaCl}$. Hari ke4 terjadi kematian beberapa spesies mikroalga, sehingga terdapat 5 spesies mikroalga yang masih bertahan hidup pada ketiga konsentrasi $\mathrm{NaCl}$. Beberapa spesies tersebut, yaitu Zygnema sp., Scenedesmus rubescens, Pediastrum tetras, Staurastrum javanicum, dan Galdieria sulphuraria. Pada hari ke- 6 terdapat 3 spesies mikroalga yang masih hidup pada ketiga variasi konsentrasi $\mathrm{NaCl}$, yaitu Scenedesmus rubescens, Galdieria sulphuraria, dan Zygnema sp. Pada hari ke- 8 sampai dengan hari ke- 25 hanya terdapat 2 spesies mikroalga yang bertahan hidup pada medium dengan ketiga konsentrasi $\mathrm{NaCl}$ tersebut. Kedua mikroalga tersebut adalah spesies Scenedesmus rubescens dan Galdieria sulphuraria. Mikroalga yang bertahan hidup pada salinitas hingga $5 \mathrm{~g} / \mathrm{L} \mathrm{NaCl}$ tersebut selanjutnya diisolasi untuk dianalisis kandungannya. Salinitas 
merupakan salah satu faktor yang mempengaruhi pertumbuhan mikroalga, masing-masing mikroalga dapat tumbuh dengan baik pada salinitas tertentu. Mikroalga yang tidak dapat bertahan hidup pada salinitas yang tinggi dikarenakan adanya penurunan proses fotosintesis dan respirasi sehingga menghambat pembentukan sel anakan (Widjaja et al., 2009).

\subsection{Morfologi isolat mikroalga}

Mikroalga yang berhasil diisolasi dilakukan identifikasi morfologi. Hasil identifikasi morfologi terhadap isolat dibandingkan dengan data morfologi yang terdapat di algabase.org yang merupakan website kumpulan data-data mikroalga yang telah diteliti dari seluruh dunia. Gambar 3 berikut merupakan morfologi isolat mikroalga yang diberi label dengan MA1 dan MA2.

Isolat MA1 merupakan spesies Scenedesmus rubescens, sedangkan MA2 merupakan spesies Galdieria sulphuraria. Kedua mikroalga tersebut termasuk divisi mikroalga hijau (Chlorophyta). Karakteristik Chlorophyta secara umum, yaitu mengandung klorofil, berwarna hijau, inti sel bersifat eukariotik, bersifat autotrof, dan habitat terbesar di air tawar (Debiagi et al., 2017).
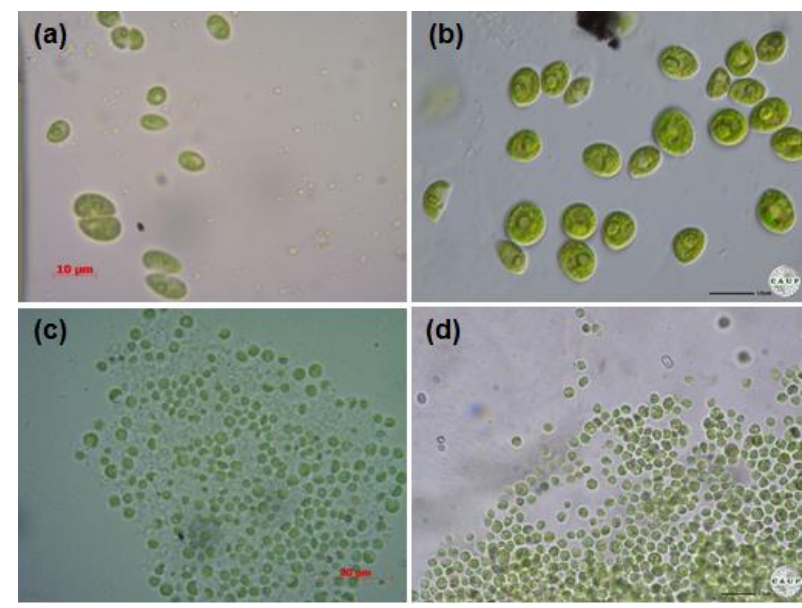

Gambar 3. Morfologi isolat mikroalga (a) isolat MA1, (b) Scenedesmus rubescens dari algabase.org, (c) isolat MA2, dan (d) Galdieria sulphuraria dari algabase.org

\subsection{Kurva pertumbuhan mikroalga seleksi medium pertumbuhan}

Laju pertumbuhan mikroalga diukur menggunakan spektrofotometer UV-Vis yang didasarkan pada peningkatan absorban pada kultur. Absorban pada kurva pertumbuhan mewakili jumlah sel pada media kultur. Semakin tinggi nilai absorban semakin banyak jumlah sel pada media pertumbuhan, dan sebaliknya nilai absorban yang rendah menunjukkan kecilnya jumlah sel pada media pertumbuhan (Vishnu and Sumathi, 2014). Kurva pertumbuhan digunakan sebagai acuan untuk menentukan waktu panen dari kultur mikroalga. Kurva pertumbuhan isolat mikroalga MA1 dan MA2 pada seleksi medium pertumbuhan terdapat pada Gambar 4.
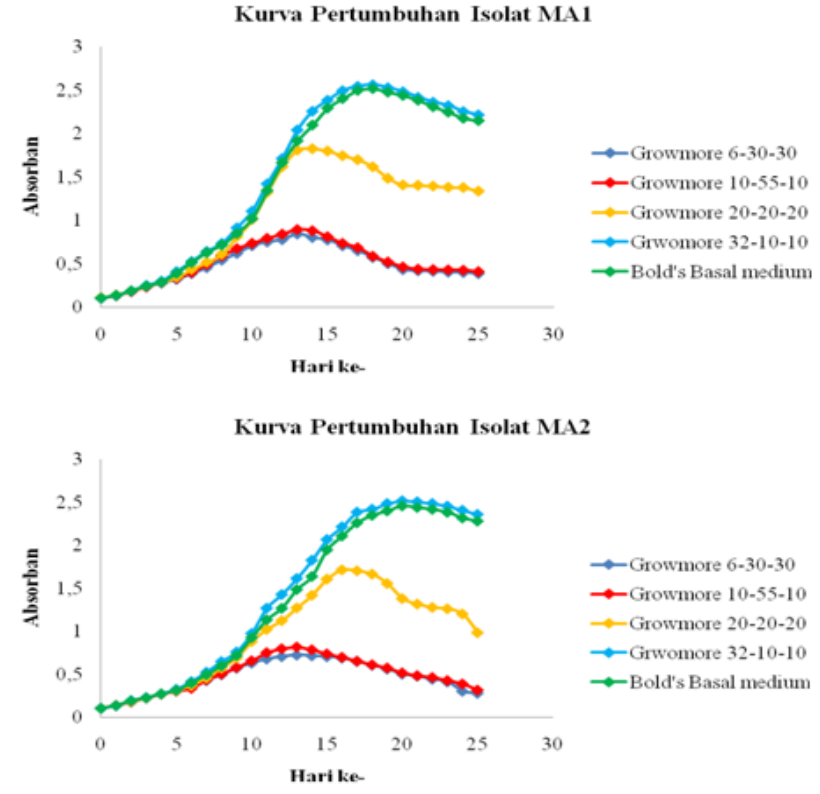

Gambar 4. Kurva pertumbuhan isolat mikroalga MA1 dan MA2 pada seleksi medium pertumbuhan

Gambar 4 memberikan informasi bahwa pertumbuhan terbaik mikroalga MA1 dan MA2 terdapat pada medium pupuk growmore 32-10-10. Hal tersebut terlihat dari tingginya nilai absorban dan waktu hidup yang lebih panjang pada kultur dalam medium pupuk growmore 32-10-10 tersebut. Pada medium Bold's Basal menunjukkan hasil yang mirip dengan growmore 32-1010. Growmore 32-10-10 merupakan medium dengan kadar nitrogen tinggi. Nitrogen merupakan salah satu komponen nutrien yang dibutuhkan mikroalga, sumber nitrogen yang berbeda dapat memberikan pengaruh yang berbeda terhadap pertumbuhan dan kandungan metabolit mikroalga. Defisiensi nitrogen dapat menyebabkan pembelahan sel terganggu, sehingga produksi biomassa berkurang (Prasad et al., 2013). Hal tersebut terjadi pada kultur mikroalga yang terdapat pada medium pupuk growmore 6-30-30, growmore 10-55-10, dan growmore 20-20-20 dengan kadar nitrogen rendah.

$\mathrm{NaNO}_{3},\left(\mathrm{NH}_{4}\right)_{2} \mathrm{HPO}_{4}$ dan urea merupakan sumber nitrogen yang paling umum digunakan pada medium pertumbuhan. Masing-masing memberikan pengaruh terhadap pertumbuhan dan kandungan metabolit mikroalga, seperti Scenedesmus dimorphus memilki pertumbuhan optimal pada medium dengan sumber nitrogen berupa urea, namun memproduksi lipid tinggi pada medium dengan $\mathrm{NaNO}_{3}$ sebagai sumber nitrogen (Rinaldi et al., 2015).

Konsentrasi sumber nitrogen juga sangat mempengaruhi pertumbuhan dan metabolisme mikroalga, mikroalga akan tumbuh dan menghasilkan produk tertentu pada konsentrasi sumber nitrogen tertentu pula. Pada mikroalga Spirulina platensis mengalami pertumbuhan lebih cepat pada konsentrasi urea $0,200 \mathrm{~g} / \mathrm{L}$ dibandingkan $0,800,1,350$, dan 1,800 g/L (Nugraha et al., 2015). 


\subsection{Berat biomassa kering mikroalga}

Berat biomassa kering mikroalga didapatkan dengan adanya kurva kalibrasi yang membentuk persamaan regresi. Tabel 1 ditunjukkan berat biomassa kering isolat mikroalga MA1 dan MA2 pada variasi medium. Berat biomassa kering mikroalga MA1, yaitu 1,040 g dalam 1 L kultur pada medium Growmore dan 1,035 g pada BBM. Mikroalga MA2 1,008 g pada medium Growmore dan 1,002 g pada BBM.

Tabel 1

Berat Biomassa Kering Mikroalga pada Variasi Medium

\begin{tabular}{lll}
\hline Mikroalga & \multicolumn{2}{l}{ Berat Biomassa Kering/Liter } \\
\cline { 2 - 3 } & BBM & Growmore \\
\hline MA1 & $1,035 \mathrm{~g}$ & $1,040 \mathrm{~g}$ \\
MA2 & $1,002 \mathrm{~g}$ & $1,008 \mathrm{~g}$ \\
\hline
\end{tabular}

\subsection{Kandungan pigmen}

Klorofil merupakan senyawa dalam kloroplas yang berperan dalam menyerap energi cahaya dalam fotosintesis. Pengukuran kandungan klorofil dapat membantu dalam penentuan tingkat pertumbuhan mikroalga, karena kandungan klorofil di dalam mikroalga sejalan dengan tingkat pertumbuhan mikroalga (Ramaraj et al., 2013).

Jenis pigmen dengan kandungan yang tinggi pada mikroalga MA1 dan MA2 adalah klorofil a, diikuti dengan klorofil $b$, sedangkan karotenoid dengan jumlah yang terendah (Tabel 2). Kandungan klorofil a lebih banyak daripada klorofil b pada kedua mikroalga. Rasio klorofil a terhadap klorofil b umumnya sebesar 2:1 (Hosikian et al., 2010). Pada beberapa mikroalga, seperti Micractinium ehime, Micractinium sp., Mychonastes rotundus juga memilki kandungan klorofil a lebih banyak daripada klorofil b (Dharma et al., 2017).

Tabel 2

Kandungan pigmen mikroalga MA1dan MA2

\begin{tabular}{lllll}
\hline \multirow{2}{*}{ Mikroalga } & \multicolumn{3}{l}{ Kandungan Pigmen $(\mu \mathrm{g} / \mathrm{mL})$} \\
\cline { 3 - 5 } & & Klorofil a & Klorofil b & Karotenoid \\
\hline \multirow{2}{*}{ MA1 } & BBM & 18,176 & 10,451 & 3,669 \\
\cline { 2 - 5 } & GM & 18,188 & 10,463 & 3,682 \\
\hline \multirow{2}{*}{ MA2 } & BBM & 18,124 & 10,195 & 3,762 \\
\cline { 2 - 5 } & GM & 18,137 & 10,206 & 3,777 \\
\hline
\end{tabular}

\subsection{Kandungan lipid}

Penggunaan nile red memudahkan skrining mikroalga yang mengandung lipid sebagai kandidat dalam produksi asam lemak untuk biodiesel (Govender et al., 2012). Mikroalga MA1 dan MA2 diindikasikan memilki kandungan lipid yang tinggi karena memiliki perpendaraan cahaya berwarna kuning terang melalui uji nile red yang diamati dengan mikroskop flourescence (Gambar 5).

Interaksi nile red dengan lipid menyebabkan warna kuning atau kuning kemerahan pada mikroalga. Trigliserida yang merupakan lipid netral ditandai dengan pembentukan warna kuning mengkilat, sedangkan lipid polar ditandai dengan pembentukan warna merah (Alemán-Nava et al., 2016).

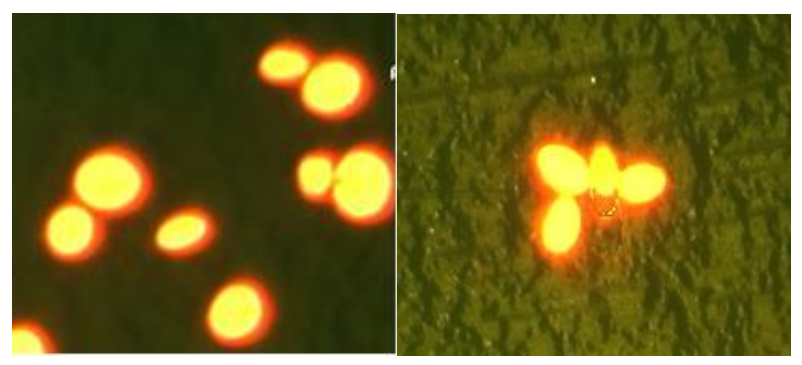

Gambar 5. Foto flourescence mikroalga (a) MA1 dan (b) MA2 dengan perbesaran 1000x

Analisis kuantitatif lipid dilakukan dengan ekstraksi menggunakan pelarut n-heksana. Heksana lebih tidak beracun dibandingkan kloroform dan pelarut organik non polar lainnya, memiliki afinitas minimal terhadap kontaminan non lipid, dan memilki selektivitas yang tinggi terhadap fraksi lipid netral (Cheng et al., 2014).

Gambar 6 menunjukkan kedua mikroalga mengandung lipid dengan kadar yang tinggi pada dua kedua jenis medium. Mikroalga MA1 mengandung $31,95 \%$ lipid pada medium Bold's Basal dan 32,4\% pada pupuk Growmore, MA2 mengandung 28,72\% lipid pada medium Bold's Basal dan 28,93 \% pada pupuk Growmore. Kandungan lipid dikatagorikan signifikan bila berkisar 20-50\% dari berat biomassa kering (Gouveia and Oliveira, 2009).

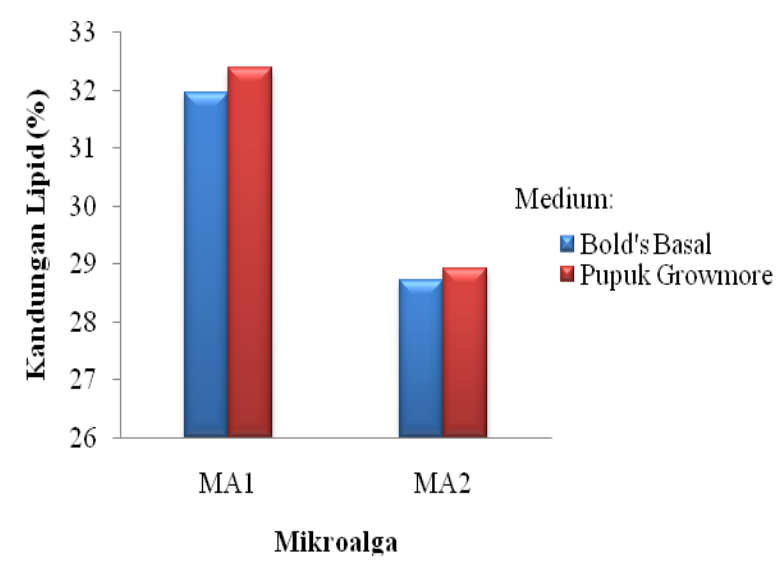

Gambar 6. Kandungan lipid isolat mikroalga MA1 dan MA2 pada medium Bold's Basal dan pupuk Growmore

\subsection{Produktivitas lipid}

Produktivitas lipid merupakan indikator yang merefleksikan kombinasi kadar lipid dan berat kering biomassa mikroalga. Produktivitas lipid memberikan gambaran yang lebih tepat dan akurat tentang potensi mikroalga dalam menghasilkan lipid. Mikroalga dengan produktivitas lipid yang tinggi selain memiliki kadar lipid yang tinggi juga memiliki produktivitas biomassa yang tinggi pula (Yang et al., 2012). Produktivitas lipid mikroalga MA1 dan MA2 pada medium Bold's Basal dan pupuk Growmore terdapat pada Gambar 7. 


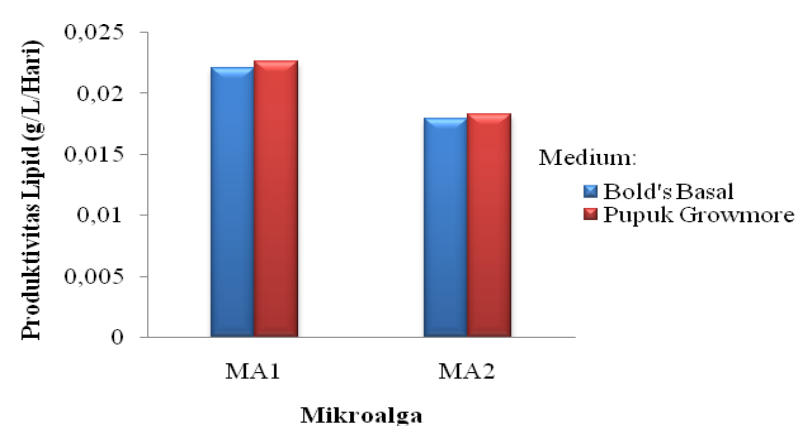

Gambar 7. Produktivitas lipid pada isolat mikroalga MA1 dan MA2

Mikroalga MA1 memiliki produktivitas lipid 0,0221 $\mathrm{g} / \mathrm{L} / \mathrm{hari}$ pada medium Bold's Basal dan 0,0226 g/L/hari pada pupuk Growmore. MA2 memiliki produktivitas lipid 0,0179 g/L/hari pada medium Bold's Basal dan 0,0183 g/L/hari pada pupuk Growmore.

\subsection{Kandungan asam lemak}

Asam lemak yang pada umumnya disintesis oleh mikroalga memiliki panjang ikatan dengan rentang C16 sampai C18 (Miao and $\mathrm{Wu}, 2006$ ). Adapun komposisi kandungan asam lemak pada mikroalga MA1 dan MA2 terdapat pada Tabel 3.

Tabel 3

Kandungan asam lemak mikroalga MA1 dan MA2

\begin{tabular}{|c|c|c|}
\hline \multirow[t]{3}{*}{ Asam lemak } & \multicolumn{2}{|c|}{$\begin{array}{l}\text { \% Kandungan } \\
\text { asam lemak }\end{array}$} \\
\hline & \multicolumn{2}{|c|}{ Mikroalga } \\
\hline & MA1 & MA2 \\
\hline Asam Miristat (C14:0) & 3,14 & - \\
\hline Asam Pentadesilat (C15:0) & 3,42 & - \\
\hline Asam Palmitat (C16:0) & 11,77 & 1,19 \\
\hline Asam Heksadekadienoat (C16:2) & 9,36 & 22,54 \\
\hline Asam Heksadekatrienoat (C16:3) & - & 19,37 \\
\hline Asam Margarat (C17:0) & 3,74 & - \\
\hline Asam Stearat (C18:0) & 13,29 & 48,01 \\
\hline Asam Oleat (C18:1) & 3,75 & 3,03 \\
\hline Asam Linoleat (C18:2) & 8,11 & 3,01 \\
\hline Asam Linolenat (C18:3) & 30,43 & - \\
\hline Asam Arakhidat (C20:0) & - & - \\
\hline Asam Heneikosilat (C21:0) & 5,36 & - \\
\hline Asam Behenat (C22:0) & - & - \\
\hline Asam Erukat (C22:1) & - & 2,85 \\
\hline Asam Dokosatrinoat (C22:3) & - & - \\
\hline Asam Lignoserat (C24:0) & 6,74 & - \\
\hline Asam Melisat (C30:0) & 5,45 & - \\
\hline ¿SFA (saturated fatty acid) & 55,66 & 49,2 \\
\hline $\begin{array}{l}\text { ¿MUFA (monounsaturated fatty } \\
\text { acid) }\end{array}$ & 3,75 & 5,88 \\
\hline $\begin{array}{l}\text { ¿PUFA (polyunsaturated fatty } \\
\text { acid) }\end{array}$ & 47,9 & 44,92 \\
\hline
\end{tabular}

Tabel 3 menunjukkan bahwa asam lemak C16 sampai C18 merupakan asam lemak dominan terdapat pada isolat mikroalga MA1 dan MA2, seperti asam palmitat (C16:0), asam stearat (C18:0), asam oleat
(C18:1), asam linoleat (C18:2), dan asam linolenat (C18:3). Asam lemak penyusun lipid adalah asam lemak jenuh (saturated fatty acid) dan asam lemak tak jenuh (monounsaturated fatty acid dan polyunsaturated fatty acid). Jumlah dan komposisi asam-asam lemak jenuh dan tak jenuh dalam lipid tergantung pada jenis sumber lipid (Martín et al., 2010).

Mikroalga MA1 dan MA2 memiliki kandungan asam palmitat (C16:0) dan asam stearat (C18:0) yang tinggi. Asam palmitat (C16:0) dan asam stearat (C18:0) merupakan asam lemak jenuh/Saturated Fatty Acid (SFA) yang digunakan sebagai sumber biodiesel (Chokshi et al., 2015). Asam palmitat (C16:0) dan asam stearat (C18:0) memiliki bilangan setana yang lebih tinggi dibandingkan dengan asam lemak lainnya, yaitu masing-masing 74,5 dan 86,9. Semakin tinggi bilangan setana (cetane number), maka semakin baik kualitas biodiesel (Chisti, 2007). Memiliki kandungan asam lemak jenuh (saturated fatty acid) yang tinggi, seperti asam palmitat (C16:0) dan asam stearat (C18:0), maka mikroalga MA2 berpotensi sebagai sumber biodiesel.

\section{Kesimpulan}

Mikroalga yang berhasil ditapis dengan stres salinitas dan diisolasi dalam penelitian ini, yaitu Mikroalga MA1 (Scenedesmus rubescens) dan MA2 (Galdiera sulphuraria). Pupuk Growmore merupakan medium yang optimal untuk pertumbuhan mikroalga MA1 dan MA2 dalam memproduksi lipid. Mikroalga MA1 memiliki kadar lipid total 32,4 \% dengan produktivitas $0,0226 \mathrm{~g} / \mathrm{L} / \mathrm{hari}$ dan MA2 memiliki kadar lipid total 28,93 \% dengan produktivitas 0,0224 g/L/hari. Mikroalga MA1 dan MA2 berpotensi sebagai sumber biodiesel dengan kandungan asam lemak jenuh (saturated fatty acid) yang tinggi masing-masing $55,66 \%$ dan $49,2 \%$ dari total asam lemak metil ester.

\section{Ucapan terima kasih}

Peneliti mengucapkan terima kasih kepada analis dan teknisi Laboratorium Biokimia, Laboratorium Genetika, Laboratorium Bioteknologi Universitas Andalas, dan Laboratorium Kesehatan Sumatera Barat serta seluruh pihak yang telah membantu dalam penyelesaian dan penyusunan jurnal penelitian ini.

\section{Daftar pustaka}

Alemán-Nava, G.S., Cuellar-Bermudez, S.P., Cuaresma, M., Bosma, R., Muylaert, K., Ritmann, B.E., Parra, R., 2016. How to us Nile Red, a selective fluorescent stain for microalgal neutral lipids. J. Microbiol. Methods 128, 74-79. https://doi.org/10.1016/j.mimet. 2016.07.011

Bartley, M.L., Boeing, W.J., Dungan, B.N., Holguin, F.O., Schaub, T., 2013. pH effects on growth and lipid accumulation of the biofuel microalgae Nannochloropsis salina and invading organisms. J. Appl. Phycol. 26, 1431-1437. https://doi.org/10. 1007/s10811-013-0177-2

Chaidir, Z., Fadjria, N., Armaini, Zainul, R., 2016. Isolation and molecular identification of freshwater 
microalgae in Maninjau Lake West Sumatra. Der Pharm. Lett. 8, 177-187.

Cheng, J., Huang, R., Li, T., Zhou, J., Cen, K., 2014. Biodiesel from wet microalgae: Extraction with hexane after the microwave-assisted transesterification of lipids. Bioresour. Technol. 170, 69-75. https://doi.org/10.1016/j.biortech.2014.07.089

Chisti, Y., 2007. Biodiesel from microalgae beats bioethanol. Trends Biotechnol. 26, 126-131. https://doi.org/10.1016/j.tibtech.2007.12.002

Chokshi, K., Pancha, I., Trivedi, K., George, B., Maurya, R., Ghosh, A., Mishra, S., 2015. Biofuel potential of the newly isolated microalgae Acutodesmus dimorphus under temperature induced oxidative stress conditions. Bioresour. Technol. 180, 162-171. https://doi.org/10.1016/j.biortech.2014.12.102

Christenson, L., Sims, R., 2011. Production and harvesting of microalgae for wastewater treatment, biofuels, and bioproducts. Biotechnol. Adv. 29, 686702. https://doi.org/10.1016/j.biotechadv.2011. 05.015

Cooksey, K.E., Guckert, J.B., Williams, S.A., Callis, P.R., 1987. Fluorometric determination of the neutral lipid content of microalgal cells using Nile Red. J. Microbiol. Methods 6, 333-345. https://doi.org/ 10.1016/0167-7012(87)90019-4

Debiagi, P.E.A., Trinchera, M., Frassoldati, A., Faravelli, T., Vinu, R., Ranzi, E., 2017. Algae characterization and multistep pyrolysis mechanism. J. Anal. Appl. Pyrolysis 128, 423-436. https://doi.org/10.1016/j.jaap.2017.08.007

Dharma, A., Sekatresna, W., Zein, R., Chaidir, Z., Nasir, N., 2017. ISSN 0975-413X CODEN (USA): PCHHAX Chlorophyll and Total Carotenoid Contents in Microalgae Isolated from Local Industry Effluent in West Sumatera, Indonesia. Pharma Chem. 9, 9-11.

Duong, V.T., Li, Y., Nowak, E., Schenk, P.M., 2012. Microalgae isolation and selection for prospective biodiesel production. Energies 5, 1835-1849. https://doi.org/10.3390/en5061835

Dyer, W.., Bligh, E.., 1959. Canadian Journal of Biochemistry and Physiology. Can. J. Biochem. Physiol. 37, 911-917. https://doi.org/dx.doi.org/ 10,1139/cjm2014-0700

Gouveia, L., Oliveira, A.C., 2009. Microalgae as a raw material for biofuels production. J. Ind. Microbiol. Biotechnol. 36, 269-274. https://doi.org/10.1007/ s10295-008-0495-6

Govender, T., Ramanna, L., Rawat, I., Bux, F., 2012. BODIPY staining, an alternative to the Nile Red fluorescence method for the evaluation of intracellular lipids in microalgae. Bioresour. Technol. 114, 507-511. https://doi.org/10.1016/j.biortech. 2012.03.024

Griffiths, M.J., Van Hille, R.P., Harrison, S.T.L., 2010. Selection of direct transesterification as the preferred method for assay of fatty acid content of microalgae. Lipids 45, 1053-1060. https://doi.org/10.1007/ s11745-010-3468-2

Gui, M.M., Lee, K.T., Bhatia, S., 2008. Feasibility of edible oil vs. non-edible oil vs. waste edible oil as biodiesel feedstock. Energy 33, 1646-1653. https://doi.org/10.1016/j.energy.2008.06.002

Hosikian, A., Lim, S., Halim, R., Danquah, M.K., 2010. Chlorophyll extraction from microalgae: A review on the process engineering aspects. Int. J. Chem. Eng. 2010. https://doi.org/10.1155/2010/391632

Lee, Y.-K., Chen, W., Shen, H., Han, D., Li, Y., Jones, H.D.T., Timlin, J.A., Hu, Q., 2013. Basic culturing techniques. in: handbook of microalgal culture Applied Phycology and Biotechnology., in: Richmond, A., Emeritus (Eds.), Handbook of Microalgal Culture-Applied Phycology and Biotechnology. Wiley Blackwell, pp. 37-68.

Litchtenthaler, H.K., Buschmann, C., 2001. Chlorophylls and Carotenoids: Measurement and Characterization by UV-VIS Spectroscopy. Curr. Protoc. Food Anal. Chem. F4.3.1-F4.3.8.

Martín, C., Moure, A., Martín, G., Carrillo, E., Domínguez, H., Parajó, J.C., 2010. Fractional characterisation of jatropha, neem, moringa, trisperma, castor and candlenut seeds as potential feedstocks for biodiesel production in Cuba. Biomass and Bioenergy 34, 533-538. https://doi.org/10. 1016/j.biombioe.2009.12.019

Mata, T.M., Almeida, R., Caetano, N.S., 2013. Effect of the culture nutrients on the biomass and lipid productivities of microalgae dunaliella tertiolecta. Chem. Eng. Trans. 32, 973-978. https://doi.org/ 10.3303/CET1332163

Mata, T.M., Martins, A.A., Caetano, N.S., 2010. Microalgae for biodiesel production and other applications: A review. Renew. Sustain. Energy Rev. 14, 217-232. https://doi.org/10.1016/j.rser.2009. 07.020

Miao, X., Wu, Q., 2006. Biodiesel production from heterotrophic microalgal oil. Bioresour. Technol. 97, 841-846. https://doi.org/10.1016/j.biortech.2005. 04.008

Minhas, A.K., Hodgson, P., Barrow, C.J., Adholeya, A., 2016. A review on the assessment of stress conditions for simultaneous production of microalgal lipids and carotenoids. Front. Microbiol. 7, 1-19. https://doi.org/10.3389/fmicb.2016.00546

Musharraf, S.G., Ahmed, M.A., Zehra, N., Kabir, N., Choudhary, M.I., Rahman, A. ur, 2012. Biodiesel production from microalgal isolates of southern Pakistan and quantification of FAMEs by GCMS/MS analysis. Chem. Cent. J. 6, 1-10. https://doi.org/10.1186/1752-153X-6-149

Nugraha, A.D., Dharma, A., Mardiah, E., Salim, M., 2015. Effect of Urea Addition on Spirulina platensis Growth for Production of Lipid and Omega-3 Fatty Acids . Res. J. Pharm. , Biol. Chem. Sci. 6, 10051009.

Patil, V., Tran, K.Q., Giselrød, H.R., 2008. Towards sustainable production of biofuels from microalgae. Int. J. Mol. Sci. 9, 1188-1195. https://doi.org/10. 3390/ijms9071188

Prasad, R.N., Sanghamitra, K., Antonia, G.-M., Juan, G.V., Benjamin, R.-G., Luis, I.-M.J., Guillermo, V.-V., 2013. Isolation, Identification and Germplasm Preservation of Different Native \&amp; lt;i\&amp;gt;Spirulina\&amp;1t;/i\&amp;gt; Species from Western Mexico. Am. J. Plant Sci. 4, 65-71. 
https://doi.org/10.4236/ajps.2013.412A2009

Praveenkumar, R., Kim, B., Choi, E., Lee, K., Park, J.Y., Lee, J.S., Lee, Y.C., Oh, Y.K., 2014. Improved biomass and lipid production in a mixotrophic culture of Chlorella sp. KR-1 with addition of coal-fired flue-gas. Bioresour. Technol. 171, 500-505. https://doi.org/10.1016/j.biortech.2014.08.112

Qiao, H., Cong, C., Sun, C., Li, B., Wang, J., Zhang, L., 2016. Effect of culture conditions on growth, fatty acid composition and DHA/EPA ratio of Phaeodactylum tricornutum. Aquaculture 452, 311317 https://doi.org/10.1016/j.aquaculture.2015. 11.011

Ramaraj, R., Tsai, D.D.W., Chen, P.H., 2013. Chlorophyll is not accurate measurement for Algal Biomass. Chiang Mai J. Sci. 40, 547-555.

Rao, A.R., Dayananda, C., Sarada, R., Shamala, T.R., Ravishankar, G.A., 2007. Effect of salinity on growth of green alga Botryococcus braunii and its constituents. Bioresour. Technol. 98, 560-564. https://doi.org/10.1016/j.biortech.2006.02.007

Raya, I., Anshar, A.M., Mayasari, E., Dwiyana, Z., Asdar, M., 2016. Chorella vulgaris and Spirulina platensis: Concentration of protein, Docosahexaenoic Acid Chorella (DHA), Eicosapentaenoic Acid (EPA) and variation concentration of maltodextrin via microencapsulation method. Int. J. Appl. Chem. 12, 539-548.

Rinaldi, R., Armaini, Salim, M., 2015. A Selection of Nitrogen Source for Biomass and Lipid Production of Scenedesmus dimorphus Microalgae. Res. J. Pharm. Biol. Chem. Sci. 6, 143-147.

Salama, E.S., Kim, H.C., Abou-Shanab, R.A.I., Ji, M.K., Oh, Y.K., Kim, S.H., Jeon, B.H., 2013. Biomass, lipid content, and fatty acid composition of freshwater Chlamydomonas mexicana and Scenedesmus obliquus grown under salt stress. Bioprocess Biosyst. Eng. 36, 827-833. https://doi.org/10.1007/s00449-013-0919-1

Vishnu, N., Sumathi, R., 2014. Isolation of fresh water microalgae Chlorella sp and its antimicrobial activity on selected pathogens. Int. J. Adv. Res. Biol. Sci. 1, 36-43.

Widjaja, A., Chien, C.C., Ju, Y.H., 2009. Study of increasing lipid production from fresh water microalgae Chlorella vulgaris. J. Taiwan Inst. Chem. Eng. 40, 13-20. https://doi.org/10.1016/j.jtice.2008. 07.007

Yang, X., Liu, P., Hao, Z., Shi, J., Zhang, S., 2012. Characterization and identification of freshwater microalgal strains toward biofuel production. BioResources 7, 686-695. 